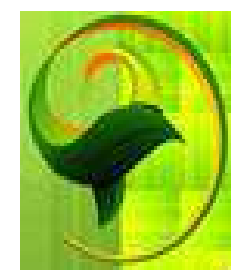

Journal Humanities: Jurnal Pengabdian kepada Masyarakat Volume 1, Nomor 1, Bulan Juni, 2020.

E - ISSN 2715-5471

Doi: https://doi.org/10.24036/jha.0101.2020.01

\title{
Assistance In Learning Basic Early Childhood Motion Skills For Early Childhood Teachers In Pesisir Selatan Regency
}

\author{
${ }^{1 *}$ Risky Syahputra, ${ }^{2}$ Syahrial Bakhtiar, ${ }^{3}$ Oktarifaldi, ${ }^{4}$ Willadi Rasyid, ${ }^{5}$ Lucy Pratama Putri \\ ${ }^{12345}$ Fakultas Ilmu Keolahragaan, Universitas Negeri Padang, Indonesia \\ Email: riskys@fik.unp.ac.id ${ }^{1}$,syahrial@fik.unp.ac.id², oktarifaldi88@fik.unp.ac.id³ \\ willrasyid@gmail.com ${ }^{4}, \underline{\text { lucy.pratama@,fik.unp.ac.id }}{ }^{5}$
}

\begin{abstract}
Based on observations, it was found that almost all teachers and PAUD educators in Pesisir Selatan district did not have the insight and skills in realizing basic motion learning. Permendiknas No. 58 of 2009 is the basis of Early Childhood Education Standards (PAUD) which have been explained in depth all aspects, contents, goals and objectives of the government in PAUD, but the reality is still far from the target. Met the implementation of PAUD in Indonesia, including in the Pesisir Selatan district, prioritizing academic content such as writing, counting and reading, looks poor providing opportunities for active play and physical activity for children. Based on research, basic motion cannot develop naturally but must be taught correctly and continuously. Community service activities for partners aim to: (a) know the importance of basic motion, (b) have skills in practicing basic motion of early childhood, (c) be able to use instruments and know the level of basic motion skills of children. The method used uses the principle that every innovation received by PAUD teachers through PIE (Preparation, Implementation and Evaluation). Submission of innovations to Partners taken through the stages of explanation, discussion, practice and evaluation and assistance in learning. . The results of the training obtained by partners as participants can be described as follows: (a) Having insight and understanding of the importance of basic movement skills, (b) having experience in practicing basic motion skills, (c) knowing and having the ability to use instruments and knowing the level of motion skills basic child.
\end{abstract}

Keywords: Assistance In Learning, Basic Motion Skill, Chilhood Theachers

\begin{abstract}
Abstrak
Berdasarkan observasi dan studi di lapangan, ditemui hampir seluruh guru dan tenaga pendidik PAUD kabupaten Pesisir Selatan belum memiliki wawasan dan keterampilan dalam merealisasikan pembelajaran gerak dasar. Permendiknas No. 58 Tahun 2009 merupakan dasar dari Standar Pendidikan Anak Usia Dini (PAUD) telah diterangkan secara mendalam segala aspek, isi, tujuan dan sasaran pemerintah dalam Pendidikan Anak Usia Dini, namun kenyataan realisasinya masih jauh dari sasaran. Ditemui pelaksanaan PAUD di Indonesia termasuk di kabupaten Pesisir Selatan sangat mengutamakan konten akademik seperti menulis, berhitung, dan membaca, terlihat sangat kurang memberikan kesempatan aktif bermain dan beraktifitas fisik kepada anak. Berdasarkan penelitian, gerak dasar tidak dapat berkembang dengan alami melainkan harus diajarkan secara benar dan kontiniu. Kegiatan pengabdian kepada masyarakat ini bagi mitra bertujuan untuk: (a) mengetahui pentingnya gerak dasar, (b) memiliki keterampilan dalam mempraktekkan gerak dasar anak usia dini, (c) mampu menggunakan instrument dan mengetahui level keterampilan gerak dasar anak. Metode yang dilakukan menggunakan prinsip bahwa setiap inovasi yang diterima oleh guru PAUD melalui PIE (Preparation, Implementationand, Evaluation). Penyampaian inovasi kepada Mitra ditempuh melalui tahapan penjelasan, diskusi, praktek serta evaluasi dan pendampingan dalam pembelajaran. Hasil pelatihan yang diperoleh mitra sebagai peserta dapat dideskripsikan sebagai berikut: (a) Memiliki wawasan dan pemahaman tentang pentingnya keterampilan gerak dasar, (b) memiliki pengalaman dalam mempraktekkan keterampilan gerak dasar, (c) mengetahui dan memiliki kemampuan menggunakan instrument dan mengetahui level keterampilan gerak dasar anak.
\end{abstract}

Keywords: Pendampingan Pembelajaran, Keterampian Gerak Dasar, Guru PAUD 
${ }^{1}$ Risky Syahputra, ${ }^{2}$ Syahrial Bakhtiar, ${ }^{3}$ Oktarifaldi, ${ }^{4}$ Willadi Rasyid, ${ }^{5}$ Lucy Pratama Putri

ANALISIS SITUASI

Pelaksanaan PAUD di seluruh Indonesia berpedoman pada Permendiknas No. 58 Tahun 2009 tentang Standar Pendidikan Anak Usia Dini (PAUD). Permendiknas ini meliputi (a) Standar tingkat pencapaian perkembangan, (b) Standar pendidik dan tenaga kependidikan, (c) Standar isi, proses, dan penilaian; (d) Standar sarana dan prasarana, pengelolaan, dan pembiayaan. Dengan demikian, PAUD memegang peranan yang sangat penting dalam mengembangkan dan menyiapkan pribadi peserta didik secara utuh dan menyeluruh. Pendidikan Anak Usia Dini merupakan salah satu jenjang awal yang paling strategis serta menentukan perjalanan dan masa depan anak secara keseluruhan, serta akan menjadi fondasi bagi penyiapan anak memasuki pendidikan dasar, menengah dan pendidikan tinggi.

Sesuai dengan teori perkembangan kognitif yang dikukakan oleh Piaget, perkembangan kognitif anak usia dini dipengaruhi oleh perkembangan keterampilan motorik, dan begitu juga sebaliknya, (Oktarifaldi, Risky Syahputra, H. Nur, W. Rasyid, 2019). Dengan demikian, anak usia dini seharusnya belajar melalui eksplorasi lingkungan yang mensyaratkan mereka lebih banyak bergerak secara aktif. Hasil studi dan observasi menemukan kegiatan PAUD di Indonesia masih belum mampu mewujudkan pencapaian motorik kasar pada anak dikarenakan anak lebih banyak pasif dan fokus pada konten akademik. Dalam hal ini Bakhtiar (2019) menyampaikan, upaya yang dapat dilakukan oleh negara untuk menghadapi tantangan global salah satunya dengan menyiapkan Sumber Daya Manusia (SDM) yang handal. Sumber daya handal yang dimaksud tidak dapat bergitu saja tercipta dalam waktu singkat, salahsatu upaya adalah memberikan perhatian terhadap pendidikan anak usia dini. Salah satu bentuk implementasi dari pemaparan ini adalah dengan mengadakan realisasi hasil penelitian yang telah banyak dilakukan berkaitan dengan motorik atau gerak. Pengabdi juga telah banyak melakukan penelitian berkaitan dengan gerak dasar, hasil dari penelitian tersebut akan disebarluaskan dan diaplikasikan tentunya melalui pengabdian kepada masyarakat.

Pada kesempatan itu pengabdi menjelaskan bahwa mengajarkan gerak dasar pada siswa merupakan hal penting yang tidak bisa disepelekan. Karena keterampilan gerak dasar yang dimiliki oleh anak akan berkorelasi dengan perkembangan kemampuan kognitif anak, seperti menulis, membaca dan berhitung (Diamond, 2000, Ericsson, 2008, Piek, Dawson, Smith, Gasson, 2008, Raczek, 2010, Westendorp, Hartman, Houwen, Smith, Visscher, 2011, Singh, Uijtdewilligen, Twisk, Mechelen, Chinapaw, van der Fels, Ewierike, Hartman, Elferink-, Smith, Visscher; mArcin, Sara, Andrzej, 2017). Berdasarkan hal tersebut, hasil temuan ahli ini mestinya dapat diterima dan disebarluaskan kepada masyarakat agar pembangunan bangsa dari sektor sumberdaya manusia yang handal akan dapat diwujudkan. Kegiatan pengabdian ini akan dapat mewadahi tujuan mulia seorang pendidik secara bertahap terutama dalam pembibitan dan pembinaan anak usia dini sebagai regenerasi bangsa, yang dimulai dengan pengenalan, pelatihan serta pembelajaran berbasis gerak yang popular dengan gerak dasar.

Gerak dasar merupakan kecakapan yang membentuk dasar dalam merealisasikan gerak yang benar. Keterampilan gerak dasar dibutuhkan dalam upaya membangun pola gerak secara kompleks dan harus mulai dikembangkan sejak usia dini yakni ketika dia mulai bergerak sesuai dengan keinginanya (Clark dan Metcalve, 2002; Haywood dan Getchell, 2009; Seefeldt, 1980). Stodden et al., (2008) menyarankan gerak dasar harus dilakukan baik itu pada anak-anak, remaja dan dewasa sebagai proses utama yang akan mempengaruhi kemampuan aktivitas fisik. Dengan demikian jika gerak dasar diajarkan ke pada anak tentunya gerakan olahraga yang kompleks juga akan dikuasai dengan baik. Belum baiknya keretampilan gerak yang ditemui di lapangan, dikarenakan guru belum memiliki wawasan dan keterampilan dalam mengajarkannya. Oleh sebab itu banyaknya anak beraktifitas fisik secara benar yang menurut ahli merupakan fondasi dalam pengembangan kognitif anak hanya sekedar teori dan belum terealisasi di sekolah.

Gerak dasar seharusnya sudah diajarkan pada lingkungan pendidikan akan tetapi penelitian membuktikan, guru PAUD di Indonesia masih belum dipersiapkan untuk menerapkan pembelajaran gerak dasar, bahkan sebahagian besar guru PAUD di Sumatera Barat belum memiliki pengetahuan, wawasan dan keterampilan tentang materi gerak dasar, (Bakhtiar \& Famelia 2017). Sebagai ketua tim penatar dan pemateri pembelajaran gerak dasar anak usia dini, pengabdi juga mendapatkan informasi langsung dari guru-guru pada seminar guru PAUD se Sumatera Barat. Mereka membenarkan keterampilan gerak dasar belum terealisasi pada anak usia dini karena guru PAUD belum memiliki wawasan dan keterampilan untuk mengajarkannya. Sedangkan penelitain membuktikan gerak dasar 


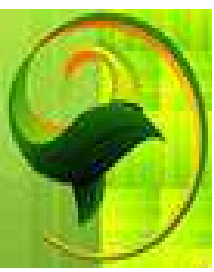

Journal Humanities: Jurnal Pengabdian kepada Masyarakat

Volume 1, Nomor 1, Bulan Juni, 2020.

E - ISSN 2715-5471

Doi: https://doi.org/10.24036/jha.0101.2020.01

tidak berkembang dengan baik secara alami, melainkan perlu dikenalkan, diajarkan dan diulang secara kontiniu.

Kemampuan gerak dalam keterampilan gerak dasar (fundamental motor skill) menggambarkan derajat penguasaan keterampilan dalam menggunakan jari-jari tangan, koordinasi mata-tangan dan mata-kaki, tempo-keseimbangan, serta persepsi visual. (Robinson, et al 2006). Kembali ditegaskan bahwa kurangnya pemahaman tenaga pendidik PAUD akan perkembangan gerak dasar dan metoda pengajarannya juga berperan besar dalam tidak tercapainya standar perkembangan motorik anak. Terlihat, masih belum baiknya kualitas dan kuantitas aktifitas fisik anak disebabkan banyak unsur yang mempengaruhi. Unsur dominan diantaranya adalah kemampuan guru dalam mengaplikasikan pembelajaran di sekolah, mereka membenarkan bahwa belum memiliki wawasan dan keterampilan tentang materi dalam mengimplementasi pembelajaran gerak dasar di PAUD/TK, (Oktarifaldi et al., 2019).

Pelaksanaan kegiatan pengabdian kepada masyarakat ini dilakukan berdasarkan temuan penelitian terdahulu serta studi dan observasi yang langsung pengabdi lakukan diberbagai kota dan kabupaten di Sumatera Barat. Terfokus di kabupaten Pesisir Selatan, ditemui permasalahan sebagai berikut : (a) Sebagian besar guru-guru PAUD di Pesisir Selatan, belum memahami bahkan belum mengenal gerak dasar. (b) Sebagian besar guru-guru PAUD di Pesisir Selatan, belum memamahami pentingnya gerak dasar bagi anak usia dini. (c) Guru-guru PAUD di Pesisir Selatan, belum memiliki keterampilan dalam mempraktekkan gerak dasar. (d) Guru-guru PAUD di Pesisir Selatan, belum mengetahui instrument tes dan level perkembangan keterampilan gerak dasar yang digunakan untuk mengetahui tingkat keterampilan gerak dasar serta cara mengevaluasinya.

Berdasarkan kondisi serta situasi tersebut, untuk mengejar ketertinggalan bagi guru-guru PAUD yang telah berada di lapangan khususnya di sekolah tempat tugas masing-masing di kabupaten Pesisir Selatan, penulis ingin mengadakan suatu sosialisasi tentang pemahaman tentang materi gerak dasar serta cara mengimplementasikan dalam pengajaran di PAUD. Setelah memahami dan memiliki wawasan kegiatan selanjutnya pengabdi akan melanjutkan dengan bimbingan dalam melihat level perkembangan serta mengevaluasi keterampilan gerak dasar. Kegiatan ini juga akan mendampingi TK/PAUD agar mampu merancang pembelajaran gerak dasar secara benar. Hal ini akan pengabdi wujudkan melalui pendampingan dan pelatihan yang dilakukan kepada guru PAUD dan TK di kabupaten Pesisir Selatan. Fokus kegiatan adalah melatih guru untuk :(a) Memiliki wawasan dan pemahaman tentang pentingnya keterampilan gerak dasar bagi anak usia dini, (b) memiliki pengalaman dalam mempraktekkan keterampilan gerak dasar anak usia dini (c) mengetahui dan memiliki kemampuan merealisasikan instrument dan level perkembangan keterampilan gerak dasar, (d) mampu merancang pembelajaran gerak dasar dan merealisasikannya di tempat tugas masingmasing secara efektif dan kontiniu.

\section{SOLUSI DAN TARGET}

Studi membuktikan banyak tenaga pengajar di TK dan PAUD kurang memperhatikan aktifitas fisik secara kuantitas dan kualitas, sehingga kondisi yang ditemui di lapangan seperti di anak-anak diberikan waktu bermain, namun kurang memperhatikan aspek keterampilan gerak dasar anak. Kesalahan dalam pelaksanaan gerak dasar saat usia dini akan bersifat permanen hingga dewasa, sehingga akan menimbulkan gangguan saat melakukan aktifitas di sekolah dan di lingkungan masyarakat. Untuk menghindari hal ini tentunya anak sejak dari dini harus dibekali dengan keterampilan gerak dasar yang baik. Jika ditelaah, komponen motorik kasar dalam Permendiknas No.58 tahun 2009 ternyata belum mencakup seluruh keterampilan gerak dasar yang semestinya dimiliki oleh anak usia dini. Sementara itu, keterampilan gerak dasar ini sangat penting dalam tumbuh kembang anak. Perkembangan gerak dasar menurut Ulrich (2000) sering diabaikan oleh para pendidik pada awal masa kanak-kanak.

Goodway dalam Sciencedaily (2010) menyatakan "banyak orang bahkan tenaga pendidik meyakini bahwa keterampilan gerak dasar berkembang secara alami, namun banyak studi yang kami lakukan menunjukkan tidaklah demikian. Hasil penelitian yang telah dilakukan oleh Universitas MacMaster Kanada, menemukan bahwa anak yang lebih sering melakukan aktivitas fisik memiliki 


\section{Assistance In Learning Basic Early Childhood Motion Skills For Early Childhood Teachers In}

Pesisir Selatan Regency

${ }^{1}$ Risky Syahputra, ${ }^{2}$ Syahrial Bakhtiar, ${ }^{3}$ Oktarifaldi, ${ }^{4}$ Willadi Rasyid, ${ }^{5}$ Lucy Pratama Putri

tingkat kemampuan gerak yang lebih baik, sebaliknya anak yang hanya melakukan aktivitas fisik beberapa kali saja dalam seminggu memiliki tingkat kemampuan gerak dasar yang lebih rendah pula (McMaster University, Kanada., 2011). Hasil penelitian yang dilakukan oleh Syahrial menunjukkan perbandingan yang signifikan antara anak yang memiliki kemampuan gerak dasar yang lebih baik diawal akan tertinggal diakhir dari anak yang kemampuan gerak dasarnya kurang sebelum diberikan perlakuan. Hal ini membuktikan bahwa, gerak dasar perlu diajarkan kepada anak. Melalui pengebdian kepada masyarakat ini diharapkan nantinya keterampilan gerak anak akan data ditingkatkan secara maksimal.

Realisasi gerak dasar yang seharusnya sudah diterapkan di sekolah terutama di TK atau PAUD belum berjalan dengan baik bukanlah kesalahan dari guru dan tenaga pendidik semata. Pada tingkat LPTK misalnya, observasi yang dilakukan ke kampus dan wawancara dengan mahasiwa program studi PAUD, memang mereka diberikan teori-teori penting tentang perkembangan dan pertumbuhan anak, akan tetapi tidak diberikan materi praktek secara mendalam tentang belajar gerak dasar. Sedangkan berdasarkan penelitian, untuk mengembangkan kemampuan kognitif memerlukan gerak yang berkualitas agar otak dapat berkembang secara optimal. Syahrial et al., (2019) Menguasai keterampilan gerak dasar ini tidak hanya mempengaruhi aspek psikomotor saja, melainkan juga pada aspek kognitif dan asosiatif. Berdasarkan permasalah ini, pengabdi yang juga merupakan ketua tim pembelajaran gerak dasar pada Universitas Negeri Padang merasa terpanggil untuk transfer pengetahuan dan temuan sebelumnya tentang hasil dari penelitian dan observasi lapangan yang telah pengabdi dilakukan beberapa tahun belakangan ini.

Berkaitan dengan kegiatan PKM ini, pengamatan yang pengabdi lakukan pada pelatihanpelatihan yang pernah diselenggarakan baik pelatihan sejenis peningkatan mutu atau pelatihan berbasis keterampilan berpikir kritis untuk guru-guru PAUD lebih banyak menitik beratkan pada pemberian informasi konsep-konsep dan teori-teori saja, penulis juga mencermati jarang sekali instruktur/fasilitator memberikan contoh konkret model pembelajaran setelah penyajian konsepkonsep atau teori-teori. Hal ini menyebabkan kesenjangan yang signifikan sehingga pengetahuan yang diperoleh guru-guru dalam kegiatan pelatihan hanya sebatas pengetahuan semata. Berdasarkan studi dan wawancara dengan guru PAUD yang ikut pelatihan, out put dari pelatihan seperti itu tidak berdampak pada kemampuan (pengetahuan dan keterampilan) guru dalam menyelenggarakan pembelajaran sains berbasis keterampilan berpikir kritis, baik pada tahap perencanaan maupun pada tahap pembelajaran di kelas. Apalagi keterampilan seharusnya setelah pelatihan guru siap untuk mengimplementasikan di tempat tugas masing-masing.

Secara umum tujuan pelatihan guru dinyatakan oleh Moekijat (1993) adalah untuk penambahan pengetahuan, keterampilan, dan perbaikan sikap dari peserta pelatihan. Peningkatan mutu guru yang dilakukan tidak akan lepas dari peningkatan kompetensi guru dan harus sesuai dengan sistem standarisasi guru di tiap-tiap jenis dan jenjang pendidikan sekolah (satndar kompetensi). Tujuan dikembangkan standar kompetensi guru adalah untuk menetapkan suatu ukuran kemampuan pengetahuan dan keterampilan yang harus dikuasai oleh seorang guru agar profesional dalam merencanakan dan mengelola proses pembelajaran di sekolah. (Suwondo, MS: 2003). Pemaparan ahli sebelumnya dapat dipahami untuk meningkatkan kompetensi guru hendaknya dilakukan dengan program terecana dan terprogram sesuai tujuan yang akan dicapai, begitu juga dalam peningkatan kompetensi guru PAUD dalam realisasikan gerak dasar kepada siswa, pengabdi sudah mempersiapkan segala macam yang diperlukan dan semua hal yang dibutuhkan dalam penyelesaian permasalahan di lapanga. Hal ini telah beberapa kali pengabdi realisasikan di tempat yang berbeda di Sumatera Barat hingga luar Sumatera Barat.

Melalui kegiatan pengabdian kepada masyarakat ini, pengabdi berasumsi dapat menambah dan menyebarluaskan pengetahuan yang baru kepada guru-guru PAUD di Sumatera Barat secara bertahap, pada kesempatan ini pengabdi memfokuskan di Pesisir Selatan. Transfer pengetahuin ini pengabdi lakukan dengan mengadakan kegiatan pelatihan yang terpusat pada daerah yang terpilih menjadi objek pengabdian. Capobianco dan Lehman (2006) dalam Witarsa (2015) menerangkan bahwa pelatihan (in-service), diartikan sebagai seluruh kegiatan yang direncanakan untuk membantu guru dalam meningkatkan pengetahuan, keterampilan, dan sikap yang diperlukan dalam melakukan tugas guru dengan baik, dan menjadi tanggung jawabnya, sehingga tujuan dapat tercapai. Menurut Oumar Hamalik (2001) bahwa pendidikan dan pelatihan merupakan suatu proses yang meliputi serangkaian upaya yang dilakukan dengan sengaja dalam memberikan bantuan kepada 


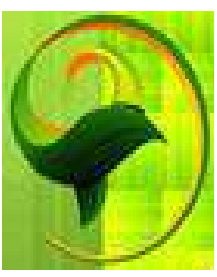

Journal Humanities: Jurnal Pengabdian kepada Masyarakat Volume 1, Nomor 1, Bulan Juni, 2020.

E - ISSN 2715-5471

Doi: https://doi.org/10.24036/jha.0101.2020.01

guru/pegawai yang dilakukan secara profesional, pelatihan dalam jangka waktu yang telah ditentukan untuk meningkatkan komitmen kerja pada bidang tugas yang ditentukan.

Pelatihan yang akan pengabdi lakukan di tempat lokasi mitra merupakan langkah awal yang harus dilakukan sebelum tindak lanjut ke langkah berikutnya. Untuk memperbaiki gerak dasar anak tentunya tidak bisa dilakukan dengan memberikan program secara langsung tanpa mengetahui sejauh mana kemampuan awal dari anak tersebut. Pendampingan dalam pelatihan mengevaluasi gerak dasar menggunakan instrument TGMD ini juga akan mengungkap kemampuan dasar dan tingkatan level gerak pada masing-masing anak. Setelah mengetahui tingkatan keterampilan gerak dasar anak, berikutnya pengabdi akan memberikan alternative solusi yang tepat dalam mengatasinya. Dapat dikatakan tanpa mengevaluasi dengan mengetahui level gerak anak mustahil kita dapat memberikan solusi atau perbaikan-perbaikan terhadap keterampilan gerak anak. Dapat diartikan bahwa pelatihan ini mengandung makna bahwa setelah mengikuti pelatihan guru akan terdorong motivasinya untuk memperbaiki kinerja, cara pembelajaran atau penyegaran ilmu dan informasi yang diperolehnya untuk direalisasikan secara tepat dan efisien.

\section{METODE PELAKSANAAN}

Pelaksanaan kegiatan pengabdian ini setidaknya dapat meningkatkan pengetahuan, dan keterampilan guru PAUD kabupaten Pesisir Selatan dalam peningkatan penguasaan keterampilan gerak dasar yang akan ditransfer kepada anak di sekolah-sekolah. Fokus kegiatan pengabdian ini adalah dalam melatih guru untuk mempraktekkan keterampilan gerak dasar, mempraktakkan dalam mengukur dan mengevaluasi gerak dasar anak menggunakan instrument test of gross motor development third edition (TGMD-3), merancang pembelajaran gerak dasar secara efektif dan merealisasikan di tempat tugas mereka masing-masing. Kegiatan penting yang harus dilakukan secara kontiniu adalah membangun komunikasi yang baik antara lembaga Universitas Negeri Padang (pengabdi) dan Mitra (guru PAUD Pesisir Selatan) setelah kegiatan dilaksanakan. Hal ini bertujuan agar kegiatan yang dilakukan tidak terputus dan akan terus berlanjut baik berupa diskusi, informasi hingga transfer ilmu dan temuan baru yang penulis dapatkan melalui riset berikutnya dengan kajian yang terkait. Tahap kegiatan pengabdian sebagai berikut :

1. Observasi dan sosialisasi ke daerah mitra (sekolah-sekolah yang terpilih)

2. Melakukan wawancara tentang materi pengabdian yang akan disampaikan

3. Membarikan beberapa pertanyaan menggunakan motode wawancara secara random ke beberapa guru di beberapa sekolah

4. Menyebarkan angket yang berisi pertanyaan, pendapat dan pengalaman guru TK dan PAUD terkait materi yang berjumlah 80 rangkap secara random melalui IGTKI Pesisir Selatan.

5. Mengumpulkan kembali angket yang telah diisi oleh perwakilan guru-guru IGTKI di Pesisir Selatan.

6. Melakukan simulasi dengan mempraktekkan Instrumen TGMD terhadap anak di TK Pembina selaku piloting kegiatan pembelajaran gerak dasar.

7. Mendiskusikan waktu pelaksanaan pengabdian dengan IGTKI Pesisir Selatan

8. Melaksanakan kegiatan pengabdian dan menyebarkan angket ke 2 setelah kegiatan dilaksanakan.

9. Melakukan pendampingan pembelajaran gerak dasar setelah kegiatan dilaksanakan dengan metode diskusi dan pemecahan masalah di daerah mitra.

\section{PELAKSANAAN KEGIATAN}

Sebelum kegiatan pengabdian dilaksanakan, tim pengabdian melakukan proses observasi terlebih dahulu kepada khalayak sasaran, guna menemukan masalah yang ada pada mitra, selanjutnya pengabdi melakukan sosialisasi dengan melakukan diskusi kebeberapa sekolah menemui guru dan kepala sekolah TK/PAUD di kabupaten Pesisir Selatan untuk berkomunikasi dan menjelaskan tujuan dan pentingnya kegiatan pengabdian ini dilaksanakan. Kegiatan pengabdian ini dilakukan melalui: 


\section{Assistance In Learning Basic Early Childhood Motion Skills For Early Childhood Teachers In}

Pesisir Selatan Regency

${ }^{1}$ Risky Syahputra, ${ }^{2}$ Syahrial Bakhtiar, ${ }^{3}$ Oktarifaldi, ${ }^{4}$ Willadi Rasyid, ${ }^{5}$ Lucy Pratama Putri

\section{Pemberian Materi}

Pemberian materi dilakukan melalui beberapa metode kepada khalayak sasaran tentang pembelajaran gerak dasar serta instrument evaluasi gerak dasar dan penggunaannya. Diantra beberapa metode tersebut adalah: metode ceramah, demonstrasi, diskusi serta pemecahan masalah, selanjutnya pengabdi melakukan pendampingan dalam realisasi materi setelah kegiatan pelatihan dilakukan. Materi yang diberikan memuat informasi tentang : (a) Wawasan pentingnya gerak dasar bagi anak usia dini, (b) Pengetahuan dan keterampilan gerak dasar bagi guru PAUD, (c) Instrument dan cara pengukuran level kemampuan gerak dasar anak bagi guru PAUD, (d) Keterampilan dalam merancang pembelajaran gerak dasar.

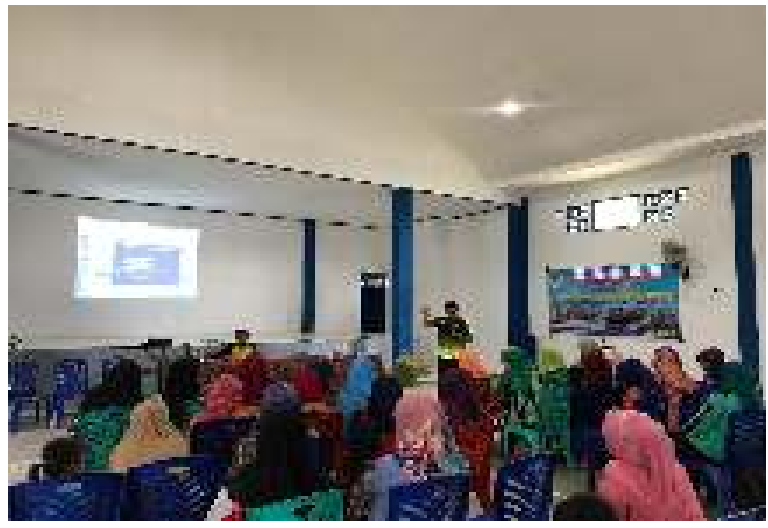

Gambar 1. Penyampaian Materi gerak dasar

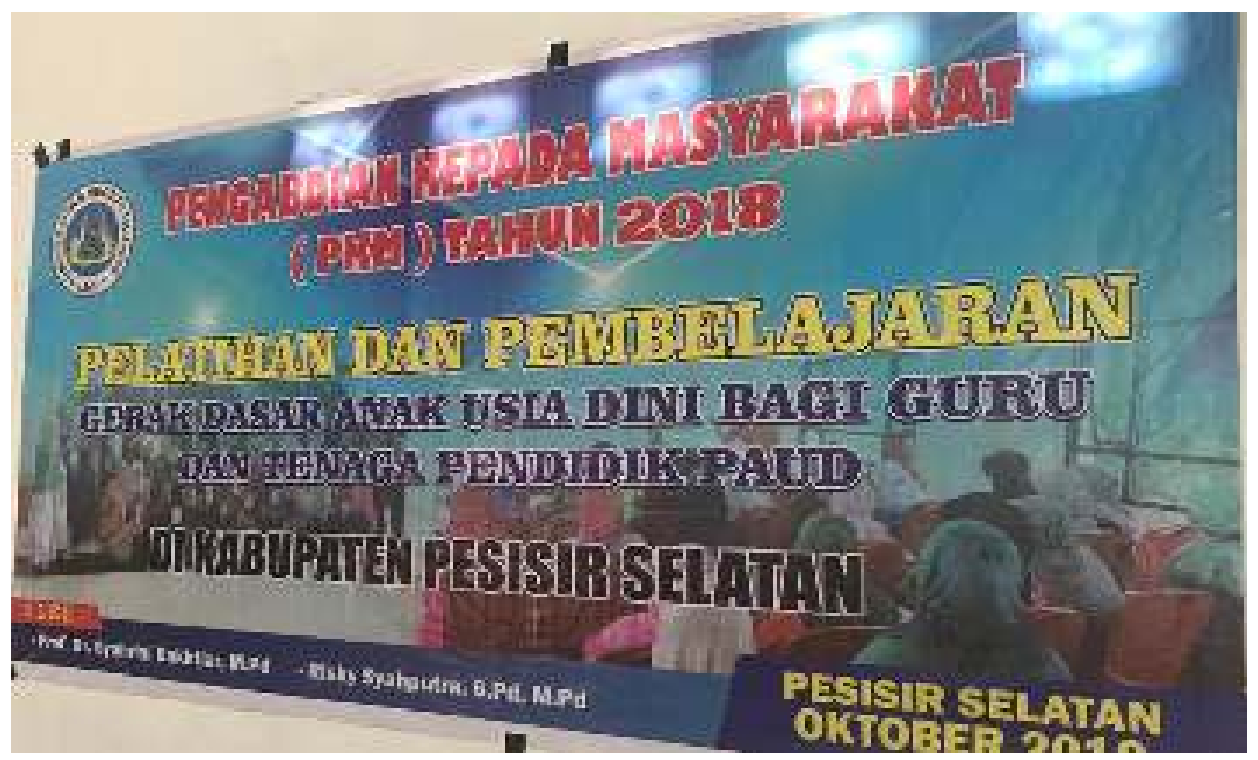

Gambar 2. Lokasi Pengabdian Kepada Masyarakat

\section{Melakukan Diskusi Tentang Materi Gerak Dasar}

Agar memiliki keterampilan yang dapat diimplementasikan langsung dalam proses pembelajaran, diskusi tentang konten materi gerak dasar dilakukan agar khalayak sasaran lebih memahami tentang hakekat dari gerak dasar. Khalayak sasaran sangat antusias dalam kegiatan diskusi ini karena mereka memiliki rasa ingin tahu yang besar tentang pentingnya gerak dasar bagi anak usia dini dan cara mengevaluasi awal kemampuan anak di TK dan PAUD. Selanjutnya pengabdi dan tim pembelajaran gerak dasar juga membimbing guru agar mengetahu level perkembanagan kemempuan gerak pada masing-masing anak. Setelah mengetahui level barulah mitra dapat memberikan solusi yang semestinya diberikan sesuai masing-masing karakter dari anak. 


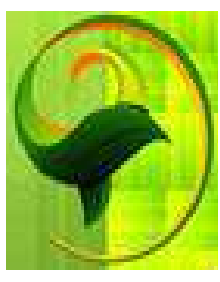

Journal Humanities: Jurnal Pengabdian kepada Masyarakat

Volume 1, Nomor 1, Bulan Juni, 2020.

E - ISSN 2715-5471

Doi: https://doi.org/10.24036/jha.0101.2020.01

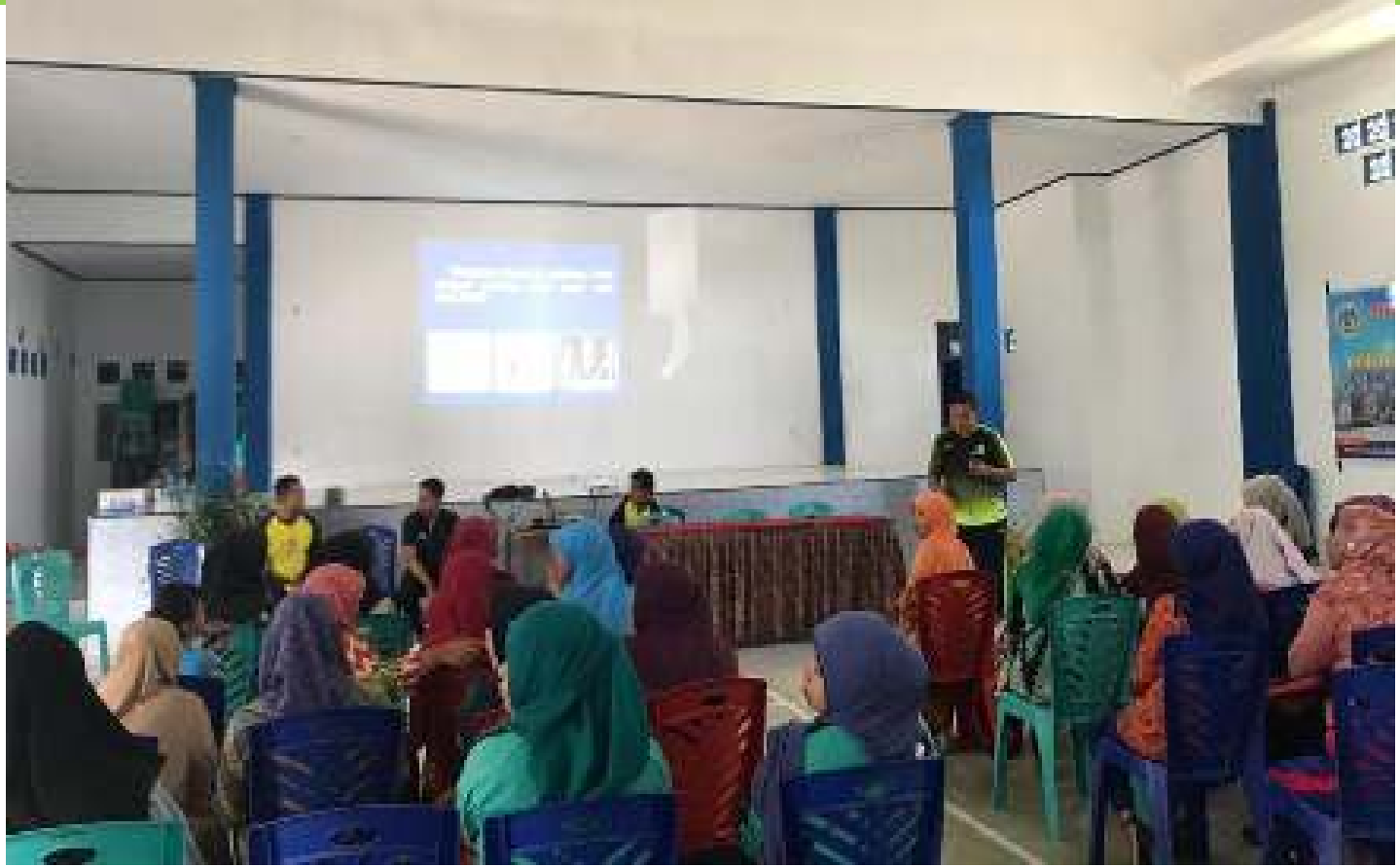

Gambar 3. Diskusi Tentang Materi Gerak Dasar Anak Usia Dini

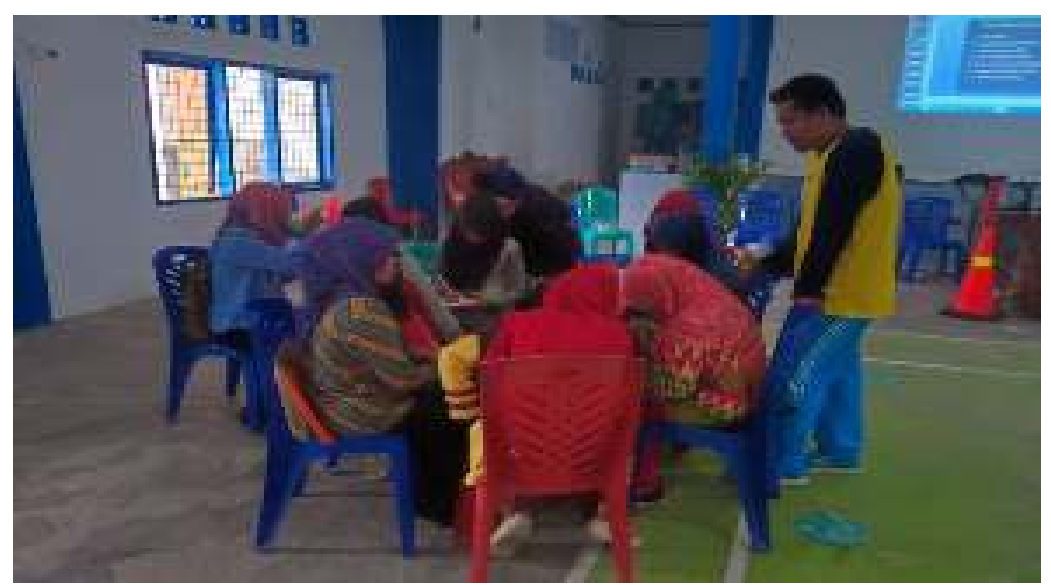

Gambar 4. Diskusi Tentang Materi Evaluasi Gerak Dasar

\section{Melakukan Praktek Pembelajaran Gerak Dasar}

Setelah meteri disampaikan dan dilanjutkan dengan diskusi berkenaan dengan substansi, sesi selanjutnya dilakukan praktek pembelajaran gerak dasar bagi masing-masing guru agar transfer pengetahuan benar-benar diserap dan dikuasai dengan baik. layaknya suatu proses pembelajaran, praktek ini bertujuan untuk mendalami dan mengetahui secara ril proses pembelajaran gerak dasar dan proses evaluasi yang akan direalisasikan guru terhadap anak di TK dan PAUD. Dalam pembelajaran dikenal dengan urutan yang dimulai dari yang mudah sampai yang agak sukar, begitu juga dalam memilih materi yang sesuai dan selaras dengan tujuan yang akan dicapai. Dalam proses ini, guru akan merasakan layaknya seorang anak dan menemukan kendala dalam proses belajar dan apa yang mesti dilakukan sebagai solusi yang tepat. 


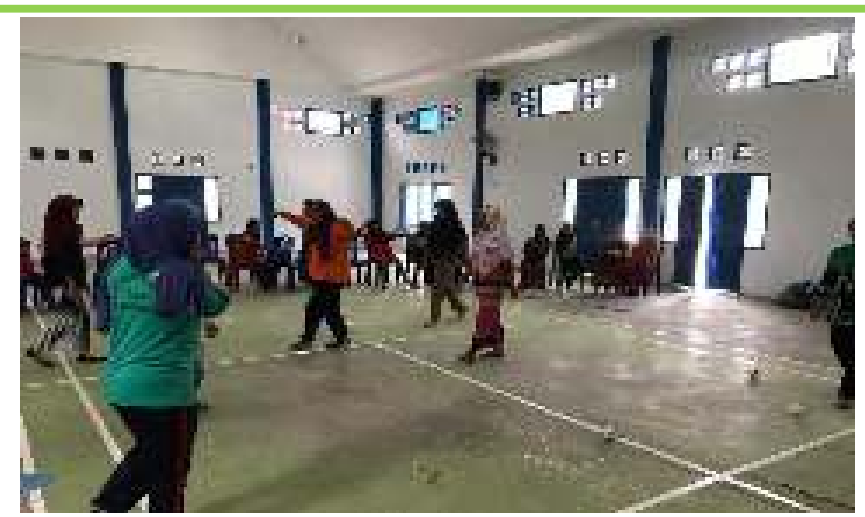

Gambar 5. Guru Sedang Demonstrasi Gerak Lokomotor

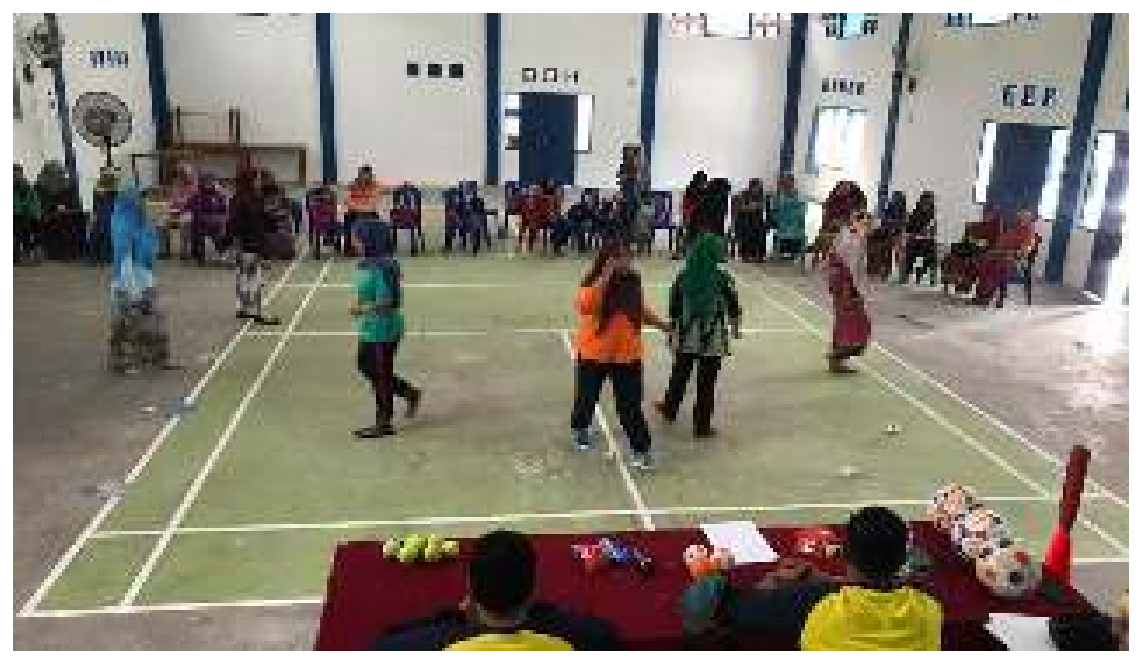

Gambar 6. Guru mempraktekkan Demonstrasi Gerak Objek Kontrol

\section{Merancang Pembelajaran Gerak Dasar}

Dalam merancang pembelajaran gerak dasar, guru dibimbing dalam merealisasikan materi yang akan disampaikan secara benar, efektif dan efisien. Materi yang disampaikan sesuai dengan pola gerak yang dianggap tidak terlalu rumit direalisasikan guru saat transisi dan saat praktek bagi anak. Gerak merupakan materi yang out put nya menuntut setiap anak bisa melakukan, bisa menganalisi, dan merealisasikan sesuai level perkembangan anak. Dalam merancang pembelajaran dibutuhkan kalaborasi antara pengetahuan, teori dan pengelaman belajar dan mengajar dari seorang guru. Implementasi tidak boleh lepas dari tujuan yang akan dicapai, baik secara kognitif, afektif dan psikomotor. Merancang pembelajaran gerak juga tidak terlepas dari pengalaman sejauh mana kemampuan anak dan level kemampuan gerak yang dimilikinya.

Realisasi pembelajaran gerak dasar disajikan berdasarkan gerak yang mendasar, diantaranya : lokomotor, non lokomotor dan objek control. Realisasi dalam mempraktekkan item gerak lokomotor dan objek control pengabdi dan Tim memberikan arahan agar pembelajaran berjalan dengan efektif, baik dalam mempersiapkan kelas, media pembelajaran, memilih materi, membuka pembelajaran, menyampaikan materi inti dan penutupan pembelajaran (evaluasi). Pengabdi dan Tim memberikan masukan kepada guru agar dapat memanfaatkan waktu sefektif mungkin. Selain efektifitas waktu hasil pembelajaran juga dapat dilihat secara langsung dengan menguasai tingkat level perkembangan gerak dasara anak. Diyakini, jika guru PAUD menguasai level perkembangan gerak dasar (objek control dan lokomotor) makan dalam merancang pembelajaran akan terasa lebih mudah dan banyak inovasi yang kreatif sehingga realisasi gerak dapat diserap anak secara efektif.

\section{HASIL DAN PEMBAHASAN}

Dalam realisasi materi pendampingan dalam pembelajaran gerak dasar bagi guru PAUD/TK di kabupeten Pesisir Selatan, pengabdi memberikan materi yang terfokus pada pengayaan instrument tes dalam melihat tingkat level kemampuan gerak dasar anak. Pengabdi menyampaikan materi yang 


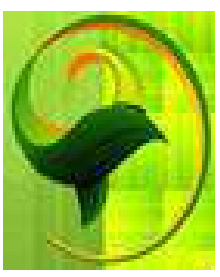

Journal Humanities: Jurnal Pengabdian kepada Masyarakat

Volume 1, Nomor 1, Bulan Juni, 2020.

E - ISSN 2715-5471

Doi: https://doi.org/10.24036/jha.0101.2020.01

nantinya akan sejalan dan sesuai dan berorientasi dalam tek kemampuan anak. Tes Keterampilan Gerak Dasar merupakan tes yang digunakan untuk mengevaluasi kemampuan gerak dasar individu, khususnya anak usia 3 hingga 10 tahun. Tujuan dari TKGD, yaitu: (a) Mengidentifikasi keterlambatan perkembangan keterampilan gerak dasar pada anak, (b) Merencanakan program instruksional untuk pengembangan keterampilan gerak dasar, (c) Menilai kemajuan perkembangan keterampilan gerak dasar individu, (d) Mengevaluasi keberhasilan program keterampilan gerak dasar, (e) Sebagai instrument pengukuran dalam penelitian yang berhubungan dengan perkembangan gerak dasar.

Material dan perlengkapan yang diperlukan untuk melaksanakan TKGD terdiri atas lembaran manual bagi penguji, lembaran untuk mencatat hasil tes dan beberapa alat adalah: (1) Bola karet dengan diameter $20-25 \mathrm{~cm}$, (2) Bola plastik ringan dengan diameter $10 \mathrm{~cm}$, (3) Bola plastik/busa diameter $7-8 \mathrm{~cm}$, (4) Bola basket, (5) Bola tenis, (6) Bola kaki, (7) Beanbag bujur sangkar ukuran 10 - $12 \mathrm{~cm}$, (8) Tongkat pemukul berbahan plastik, (9) Kerucut pendek (half cones), (10) Tiang tempat bola (batting tee), (11) Penanda lantai (kapur, atau lakban, atau polyspots). Dalam pelaksanaan tes TKGD setiap anak memerlukan waktu sekitar 15-20 menit. Selain itu diperlukan waktu tambahan untuk persiapan dan pembersihan alat sekitar 10 menit. Agar waktu pelaksanaan tes berjalan optimal, sediakan alat dalam jumlah yang cukup, misalnya bola dan pemukul, lalu kondisikan anak beralih dari satu tes ke tes lain dengan cepat. Biasanya hanya diperlukan satu sesi saja untuk melaksanakan seluruh tes tapi untuk membiasakan anak dengan lingkungan maka berikanlah beberapa sesi agar evaluasi menjadi lebih optimal.

Berdasarkan hasil survey yang telah pengabdi lakukan sebelum dan setelah dilakukanya kegiatan pengabdian kepada masyarakat (PKM) di kabupaten Pesisir Selatan, dalam hal ini, untuk melihat tingkat wawasan dan pengetahuan guru TK/PAUD pengabdi memberikan sebanyak 10 item pertanyaan terkait dengan keterampilan gerak dasar yang harus mereka pahami untuk mengimplementasikan ilmu yang dimiliki. Pertanyaan yang pengabdi ajukan merupakan data awal yang mesti didapatkan agar materi yang disampaikan tepat sasaran sesuai permasalahan mitra di Pesisir Selatan. Beberapa kegiatan serupa yang telah dilaksanakan, ditemui setiap permasalahan tidak persis sama dan solusi yang diberikan juga disesuaikan dengan apa yang semestinya dibutuhkan oleh guru. Dengan data awal ini pengabdi dan tim akan menyusun alternative pemecahan permasalahan mitra agar realisasi pengetahuan baru bagi mereka dapat diimplementasikan secara tepat. Materi pembelajaran gerak dasar yang diberikan juga akan direalisasikan oleh guru di tempat tugas masingmasing dan sejalan dengan perkembangan dan pertumbuhan fisik motorik siswa TK/PAUD yang mereka didik. Terdapat perbedaan yang signifikan antara pengetahuan, persepsi dan keterampilan guru TK/PAUD Pesisir Selatan sebelum dan sesudah pendampingan dilakukan. Adapun peningkatan tesebut sebagai berikut:

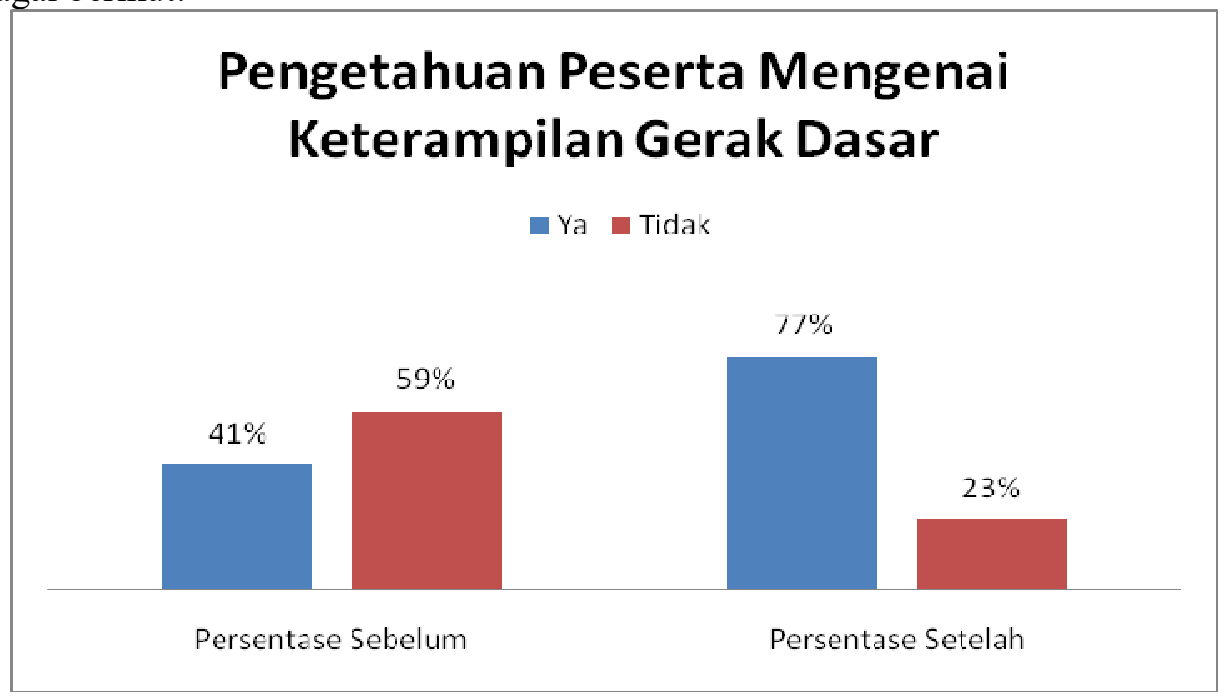

Gambar 7. Histogram Pengetahuan Guru Sebelum dan Sesudah Pelatihan 
${ }^{1}$ Risky Syahputra, ${ }^{2}$ Syahrial Bakhtiar, ${ }^{3}$ Oktarifaldi, ${ }^{4}$ Willadi Rasyid, ${ }^{5}$ Lucy Pratama Putri

Berdasarkan table distribusi di atas dapat sama-sama kita lihat bahwa pada masa sebelum dilakukanya pengabdian mengenai keterampilan gerak dasar kepada guru-guru yang ada di kabupaten Pesisir Selatan terlihat bahwa pengetahuan dan pemahaman yang mereka miliki sangat mengkhawatirkan. Padahal kita semua tahu bahwa keterampilan gerak dasar merupakan hal yang sangat urgen yang harus diajarkan sedini mungkin kepada anak. Keterampilan ini tidak akan bisa berkembang dengan sempurna tanpa diberikan ransangan berupa latihan dan pengulangan yang berkesinambungan. Namun sayangnya, masih banyak keterbatasan guru-guru TK/PAUD di kabupaten Pesisir Selatan ini. Misalnya pada item pertanyaan pertama yang pengabdi buat dalam bentuk kuesioner yang berbunyi "Apakah ibu-ibu tahu bahwa keterampilan gerak dasar ini harus diajarkan sejak usia dini?". Rata-rata dari para guru menjawab "Tidak". Pada saat proses pembelajaran berlangsung di sekolah, memang para guru sering mengajak siswanya untuk melakukan aktivitas fisik seperti bermain kejar-kejaran, lempar lemparan serta memukul benda. Namun guru-guru tersebut tidak mengetahui secara pasti tujuan dari pelaksanaan kegiatan tersebut yang mereka tahu adalah bahwa aktivitas yang demikian berguna untuk meningkatkan kebugaran jasmani anak. Serta aktivitas yang demikian ini dapat menghilangkan rasa jenuh siswa ketika belajar.

Padahal secara teoritis, melakukan aktivitas fisik seperti itu tidak hanya dapat meningkatkan kebugaran jasmani dan menghilangkan rasa jenih pada siswa. Namun lebih jauh hal ini dapat mengembangkan kemampuan kognitif, afektif dan psikomotorik secara bersamaan. Karena keterampilan gerak dasar yang dimiliki oleh anak akan berkorelasi dengan perkembangan kemampuan kognitif anak, seperti menulis, membaca dan berhitung (Diamond, 2000, Ericsson, 2008, Piek, Dawson, Smith, Gasson, 2008, Raczek, 2010, Westendorp, Hartman, Houwen, Smith, Visscher, 2011 , Singh, Uijtdewilligen, Twisk, Mechelen, Chinapaw, van der Fels, Ewierike, Hartman, Elferink-, Smith, Visscher; mArcin, Sara, Andrzej, 2017). Hal ini telah dibuktikan dalam ratusan penelitian yang telah dilakukan oleh banyak ahli diberbagai belahan dunia. Selain itu memiliki keterampilan gerak dasar bisa meningkatkan kemampuan bersosialisasi anak di masyarakat dan mengurangi dampak bullying terhadap anak-anak sedini mungkin. Anak-anak adalah pribadi yang senang bermain dengan kelompoknya.

Anak yang memiliki kemampuan motorik yang cakap otomatis lebih disenangi dilingkungan pergaulanya dan akan selalu diikutsertakan dan menjaddi pilihan utama dalam aktivitas bermain. Hal ini tentu saja akan meningkatkan rasa percaya diri pada anak tersebut. Sedangkan anak dengan kemampuan motorik yang lemah, akan selalu menjadi pilihan terakhir dalam pemilihan pemaian. Hal ini tentu saja akan membbuat anak merasa minder dan dikucilkan dari lingkungan permainanya. Disinilah peran guru PAUD dan TK sangat dibutuhkan untuk menumbuh kembangkan keterampilan gerak dasar anak secara baik dan efisien. Berdasarkan hasil penelitian, terbukti terdapat perbedaan kemampuan keterampilan gerak dasar khususnya object control antara kelompok anak yang diberi feedback langsung dan tidak langsung, ditemukan bahwa kemampuan gerak dasar anak yang diberikan feedback langsung memiliki nilai rata-rata yang lebih tinggi jika dibadingkan dengan keterampilan gerak dasar anak yang diberikan tidak langsung, Bakhtiar Dkk (2020).

\section{DISKUSI}

Pengabdian ini telah selesai dilaksanakan pada Oktober 2018 di Kabupaten Pesisir Selatan. Kegiatan ini dihadiri oleh Kepala Seksi bidang Pendidikan Anak Usia Dini kabupaten Pesisir Selatan dan ketua KKG TK dan utusan dari guru-guru TK dan PAUD Se kabupaten Pesisir Selatan yang berjumlah 40 peserta. Setelah mendapatkan wawasan, keterampilan dan pengalaman dalam pengetahuan serta pelaksanaan pembelajaran gerak dasar, kegiatan selanjutnya adalah monitoring dan pendampingan dalam mengimplementasikan materi. Hal tersebut pengabdi lakukan demi terealisasinya tujuan pengabdian kepada masyarakat secara efektif. Rangkaian kegiatan selanjutnya adalah monitoring dan pendampingan yang pengabdi lakukan terhadap mitra. Pendampingan I dalam implementasi pembelajaran oleh mitra (guru yang ikut pelatihan) dilaksanakan pada bulan November 2018, tim pembelajaran gerak dasar hadir mendampingi dan berdiskusi dengan guru tentang implementasi materi dan membantu memecahkan permasalahan yang ditemui guru PAUD/TK saat penyampaian materi. Pendampingan II dilaksanakan pada tanggal Desember 2018, hal ini terfokus pada diskusi dan perbaikan metoda yang disampaikan oleh guru sesuai dengan kondisi sekolah dan sarana yang dimiliki. Pengabdi dan mitra juga berdiskusi tentang hal-hal yang dianggap perlu untuk kelanjutan kegiatan dan membangun komunikasi dengan mitra secara kontiniu. Pengabdi dan tim 
Journal Humanities: Jurnal Pengabdian kepada Masyarakat Volume 1, Nomor 1, Bulan Juni, 2020.

E - ISSN 2715-5471

Doi: https://doi.org/10.24036/jha.0101.2020.01

pembelajaran gerak dasar selalu siap bersedia membantu dan memberikan masukan jika sekiranya masih ada hal-hal yang penting dan harus melahirkan solusi yang tepat dalam pembelajaran. Kendala yang ditemui guru di kabupaten pesisir selatan secara umum dapat diselesaikan secara baik dan sesuai dengan tujuan dan harapan. Hingga pertengahan tahun 2019 melalui whats up group, komunikasi yang baik dan membangun masih terjalin antara tim dan mitra, jika sekiranya ada kendala masih dilakukan diskusi yang berorientasi pada pemecahan masalahtim dengan cepat memberikan masukan dan solusi.

\section{KESIMPULAN}

Berdasarkan kegiatan Pengabdian Kepada Masyarakat yang sudah dilaksanakan di kabupaten Pesisir Selatan, dapat disimpulkan sebagai berikut:

1. Pelaksanaan Kegiatan Pengabdian Kepada Masyarakat ini telah berhasil dilaksanakan dengan baik tanpa mengalami kendala yang berarti.

2. Kegiatan Kegiatan Pengabdian Kepada Masyarakat ini memberikan edukasi bermanfaat kepada masyarakat (guru, orang tua, peserta didik) kabupaten Pesisir Selatan

3. Mengenai defenisi, pemahaman dan wawasan mengenai pembelajaran keterampilan gerak dasar anak usia dini bagi guru PAUD di kabupaten Pesisir Selatan.

4. Kegiatan Pengabdian Kepada Masyarakat ini memberikan gambaran dan fakta yang terjadi secara umum mengenai kemampuan anak serta pentingnya pembelajaran gerak dasar anak usia dini.

5. Kegiatan ini secara keseluruhan telah memberikan pengetahuan dan pengalaman bagi guru dalam mendemonstrasikan serta merancang pembelajaran gerak dasar anak usia dini kepada mitra (guruguru PAUD). Selanjutnya guru PAUD di kabupaten Pesisir Selatan telah mampu merancang pembelajaran gerak dasar yang kreatif sesuai kebutuhan anak.

\section{PENGAKUAN}

Terimakasih kami sampaikan kepada Kemenristeg Dikti dan seluruh jajaran pimpinan Universitas Negeri Padang melalui LP2M yang telah berkenan memberikan kesempatan dan penyalur dana dalam pembiayaan pengabdian kepada masyarakat ini. Ucapan terimakasih yang tak terhingga kepada pemerintah daerah kabupaten Pesisir Selatan melalui Dinas Pendidikan dan Kebudayaan IGTKI dan KKG-TK Pesisir selatan yang telah memfasilitasi pengabdi dalam melakukan kegiatan ini. Ucapan terimakasih kepada tim pembelajaran gerak dasar dan rekan-rekan dosen serta teman sejawat yang telah memberikan dukungan dan bantuan moril hingga pengabdian ini selesai dilaksanakan.

\section{DAFTAR PUSTAKA}

Peraturan Menteri Pendidikan Nasional Republik Indonesia No. (58). Tahun 2009 Tentang Standar Pendidikan Anak Usia Dini. Direktorat Pembinaan TK dan SD.

Syahputra, R., Nur, H., Rasyid, W., \& Mariati, S. (2019). Implementation of Basic Motion Learning and Use of Test Instrument of Gross Motor Development (TGMD) in Evaluating Basic Motion Skills. Jurnal Humanities Pengabdian Kepada Masyarakat, 1(1), 1-9.

Bakhtiar, S., Oktarifaldi, O., \& Putri, L. P. (2019). Implementation of Learning and Fundamental Motor Skill Measurement of Early Childhood Motor Skill for PAUD Teachers in Padang Panjang City. Jurnal Humanities Pengabdian Kepada Masyarakat, 1(1), 36-47.

Morgan, D., Diamond, D. M., Gottschall, P. E., Ugen, K. E., Dickey, C., Hardy, J., ... \& Connor, K. (2000). A $\beta$ peptide vaccination prevents memory loss in an animal model of Alzheimer's disease. Nature, 408(6815), 982-985.

Piek, J. P., Dawson, L., Smith, L. M., \& Gasson, N. (2008). The role of early fine and gross motor development on later motor and cognitive ability. Human movement science, 27(5), 668-681. 
${ }^{1}$ Risky Syahputra, ${ }^{2}$ Syahrial Bakhtiar, ${ }^{3}$ Oktarifaldi, ${ }^{4}$ Willadi Rasyid, ${ }^{5} L u c y$ Pratama Putri

Raczek, J. (2010). Antropomotoryka: teoria motoryczności człowieka w zarysie. Wydawnictwo Lekarskie PZWL.

Goodway, J. D., \& Robinson, L. E. (2006). SKIPing toward an active start: Promoting physical activity in preschoolers. Beyond the Journal: Young Children, 61(3), 1-6.

Westendorp, M., Hartman, E., Houwen, S., Smith, J., \& Visscher, C. (2011). The relationship between gross motor skills and academic achievement in children with learning disabilities. Research in developmental disabilities, 32(6), 2773-2779.

Korbecki, M., Wawrzyniak, S., \& Rokita, A. (2017). Fundamental movement skills of six-to sevenyear-old children in the first grade of elementary school: A pilot study. Baltic Journal of Health and Physical Activity. The Journal of Gdansk University of Physical Education and Sport, 9(4).

Clark, J. E., \& Metcalfe, J. S. (2002). The mountain of motor development: A metaphor. Motor development: Research and reviews, 2(163-190), 183-202.

Haywood, K. M., \& Getchell, N. (2019). Life span motor development. Human kinetics.

Stodden, D. F., Goodway, J. D., Langendorfer, S. J., Roberton, M. A., Rudisill, M. E., Garcia, C., \& Garcia, L. E. (2008). A developmental perspective on the role of motor skill competence in physical activity: An emergent relationship. Quest, 60(2), 290-306.

Bakhtiar, S., \& Famelia, R. (2017, December). Institute Role of Teachers' Education in Improving the Standard of Development Achievement Rate and Standard of Teacher and Education Personnels of Early Childhood Education. In International Conference of Early Childhood Education (ICECE 2017). Atlantis Press.

Oktarifaldi, O., Syahputra, R., Putri, L. P., \& Bakhtiar, S. (2019). The Effect Of Agility, Coordination And Balance On The Locomotor Ability Of Students Aged 7 To 10 YearS. Jurnal Menssana, 4(2), 190-200.

Ulrich, D. A. (2000). Test of gross motor development 2nd edition. Austin, TX: PRO-ED.

American Heart Association. (2010). Students' physical fitness associated with academic achievement; organized physical activity. ScienceDaily.

Chowdhury, A. T. (2011). Travel behavior-built environment nexus: an investigation in the context of Halifax Regional Municipality (Doctoral dissertation).

Bakhtiar, S., Putra, E. R., Oktarifaldi, O., \& Putri, L. P. (2019). The Effect Of Eye-Hand Coordination And Gender On The Level Of Ability In The Control Object Of Paud Students In Pariaman City. Jurnal Menssana, 4(2), 165-174.

Moekijat, D. (1993). Teori Komunikasi. Bandung: Mandar Maju, hal, 6(21), 145.

Suwondo, MS. (2003). Guru di Indonesia. Jakarta: Dittendik Dirjen Dikdasmen

Witarsa, R. (2015). Pengembangan Program Pelatihan Untuk Meningkatkan Kompetensi Guru Dalam Memfasilitasi Keterampilan Berpikir Kritis Anak Usia Dini. Tunas Siliwangi: Jurnal Program Studi Pendidikan Guru PAUD STKIP Siliwangi Bandung, 1(1), 46-62.

Hamalik, O. (2001). Proses Belajar dan Mengajar. Jakarta: PT Bumi Aksara. 
Journal Humanities: Jurnal Pengabdian kepada Masyarakat Volume 1, Nomor 1, Bulan Juni, 2020. E - ISSN 2715-5471

Doi: https://doi.org/10.24036/jha.0101.2020.01

Bakhtiar, S., Khairuddin, K., \& Yelis, R. (2020). PENGARUH UMPAN BALIK, KOORDINASI TERHADAP KEMAMPUAN OBJEK KONTROL SISWA PAUD KOTA PADANG PANJANG. Sporta Saintika, 5(1), 59-72. 